\title{
Inverse model method for estimating assimilation by aquatic invertebrates
}

\author{
John T. Lehman*, Robert Foy** and Donna A. Lehman \\ Department of Biology, Natural Science Building, University of Michigan, Ann Arbor, MI 48109, \\ USA
}

Key words: Bythotrephes, prey detection, digestion time, inverse models, assimilation.

\begin{abstract}
Physiological data indicate that a 3-compartment model appropriately represents ingestion, assimilation, and accumulation of somatic and reproductive tissue by an aquatic invertebrate predator. A secondary production model calibrated to growth and respiration data is used to constrain the model equations. Inverse solution methods are used to estimate rate constants for digestion and for net accrual of tissue by growing animals at different temperatures. Predicted time to $50 \%$ maximum digestion matches well with the empirical rate of digestion of prey enzymes in the predator gut. Model-derived digestion rates are consistent with the assimilation rate constant obtained by independent radiotracer methods, and with experimental detection time for prey enzymes. The model approach permits parameter estimation within a complex system of equations so that results can be compared with experimental data.
\end{abstract}

\section{Introduction}

Models of secondary production for planktonic invertebrates have developed along two main lines of approach. One approach is the birth and death rate analysis method based on egg ratio data (e.g., Edmondson, 1960, 1965), and the other is that of biomass accrual and mass balance (e.g., Parsons et al., 1984). The former method is highly informative for well defined populations, and is the method of choice when populations can be characterized over time (e.g., Hall, 1964; Wright, 1965), but it requires precise knowledge of population dynamics that must be gained by repeated census. The latter method is applicable even if a population is censused only once, because it estimates changes in mass from snapshot attributes of the target population and from environmental conditions. For that reason, it has been the method of choice for studies of populations in large pelagic systems where it is difficult or impossible to delineate and sample the same

\footnotetext{
* Corresponding author, e-mail: jtlehman@umich.edu

** Current address: Dept. of Fisheries and Wildlife, University of Alaska, Fairbanks, Alaska.
} 
subpopulation reliably over time. Moreover, models based on mass balance and material flux can be linked across trophic levels; such models provide a way to estimate rates of grazing or predation that are dictated by calculated production rates.

We adopted the biomass accrual approach for secondary production modeling in a series of reports about an invertebrate predator, Bythotrephes cederstroemi, which has become established in the North American Great Lakes (e.g., Burkhardt and Lehman, 1994; Lehman and Branstrator, 1995; Lehman et al., 1997). Our models synthesize patterns of growth and metabolism based on empirical measurements of respiration, ingestion, assimilation, development, and body mass at different temperatures and from different lakes. In common with all such bioenergetic or mass balance models, the accounting for tissue mass is set by the magnitudes of gains and losses reported as ingestion, egestion, and respiration.

Secondary production models are judged by their consistency with empirical data. The evaluative data include not only the magnitudes of gains and loss terms for tissue mass, but also the rates of various constituent processes and dynamics. For instance, model-based estimates of ingestion and assimilation by dual isotope methods (Lehman, 1993) agreed with ingestion efficiencies measured in independent experiments by Burkhardt (1991) and Burkhardt and Lehman (1994). The dual isotope measurements also provided information about turnover rates of ingested material in the predator gut (Lehman and Branstrator, 1996). Up to this time, however, there has been no report testing the tracer-inferred digestion rates by independent means. Independent analyses might confirm or dispute the predictions and inferences.

Prey proteins are important dietary components of prey, from the nutritional standpoint of a predator. Information about the time courses of digestion of prey proteins can be obtained by focusing on a subset of prey proteins that are easily detectable in their native form. These are the characteristic allozymes of metabolic enzymes that had been common targets of population genetics investigations in earlier years. Prey identification by gel electrophoresis of allozymes provides a method of unique potential. Efforts to identify prey by enzyme electrophoresis (e.g., Murray and Solomon, 1978; Giller, 1982, 1984, 1986; Lister et al., 1987) focused heavily on freshwater arthropod predators during the late 1970s and 1980s, before the allozyme methods were supplanted by more sophisticated techniques, such as enzyme-linked immunosorbent assay (ELISA) with monoclonal antibodies (Sopp et al., 1992; Hagler and Naranjo, 1994). Since then, few studies have tried to use allozymes to identify unknown prey (Hartman and Garton, 1992; Schulz and Yurista, 1995). Murray and Sullivan (1978) originated the allozyme method for diet studies; they used polyacrylamide gel electrophoresis of prey esterases to detect predation by mites. Use of these initially promising methods to identify specific feeding histories of predators drawn from nature ultimately failed (Sutherland, 1988) owing in part to what Giller (1986) called "Type B error". Giller reported spurious inferences of prey presence in as many as $45.5 \%$ of field collected predators whose gut states precluded valid prey detection based on laboratory calibration. Giller concluded that prey detection from field collections would require "properly controlled blind trials and independent identification of prey". 
Despite general abandonment of allozyme methods in the late 1980s as a valid way to identify unknown contents of predator guts, it is still possible to use the methods to measure the time course of digestion of known prey in controlled feeding trials. After consultation with P. Herbert (personal communication to JTL, 1990) about the aforementioned limitations, we tested 20 enzyme systems and selected several likely candidates for experimentation based on differences in electrophoretic mobilities of the enzymes present in predators and known experimental prey.

This communication reports model developments and empirical data that better define a secondary production model for the invertebrate predator Bythotrephes. Specifically, we incorporate separate biomass compartments for (1) ingested material, (2) metabolically labile constituents, and (3) structural tissue. Fluxes among pools, and rate constants for turnover times, are obtained by inverse solution methods for the model system of equations under constraints of measured kinetic processes. The result is a model approach that could be applied to herbivores as well as predators, subject to availability of suitable physiological rate measurements for the target organism.

\section{Conceptual Model}

We formulated a 3-compartment model to approximate the bulk growth dynamics of an actively feeding and growing organism (Fig. 1). The animal gains mass by Ingestion, and loses mass mainly by Respiration and Egestion:

$$
\begin{aligned}
& \text { Egestion }=\text { Ingestion } \times(1-\mathrm{AE}) \\
& \text { or alternatively } \\
& \text { Assimilation = Ingestion } \times \mathrm{AE}
\end{aligned}
$$

where AE is Assimilation Efficiency. The accounting is in units of carbon mass. The internal dynamics for carbon within the animal involve fluxes from the gut compartment $\left(\mathrm{C}_{\mathrm{I}}\right)$ to a compartment of labile metabolic constituents $\left(\mathrm{C}_{\mathrm{L}}\right)$, and then to a pool of more stable, structural tissue $\left(\mathrm{C}_{\mathrm{S}}\right)$. The fluxes are represented as being unidirectional, to represent the net flux terms for an animal that is feeding and gaining weight. Under conditions of starvation, the flux rate indicated by the constant $k_{2}$ would be a negative number, to demonstrate a return flux from $C_{S}$ to $C_{L}$ owing to catabolic breakdown of storage materials. In this development, the model is regarded to represent a growing animal, and $\mathrm{k}_{2}$ is the net, positive flux rate constant from $\mathrm{C}_{\mathrm{L}}$ to $\mathrm{C}_{\mathrm{S}}$. This formulation is based on model developments by Conover and Francis (1973), Lampert and Gabriel (1984), and Lehman and Naumoski (1985), with the exception that we do not consider here the dynamics of pools external to the modeled animal.

Total animal carbon mass $\left(\mathrm{C}_{\mathrm{TOT}}\right)$ is defined as the sum:

$$
\mathrm{C}_{\mathrm{TOT}}=\mathrm{C}_{\mathrm{I}}+\mathrm{C}_{\mathrm{L}}+\mathrm{C}_{\mathrm{S}}
$$




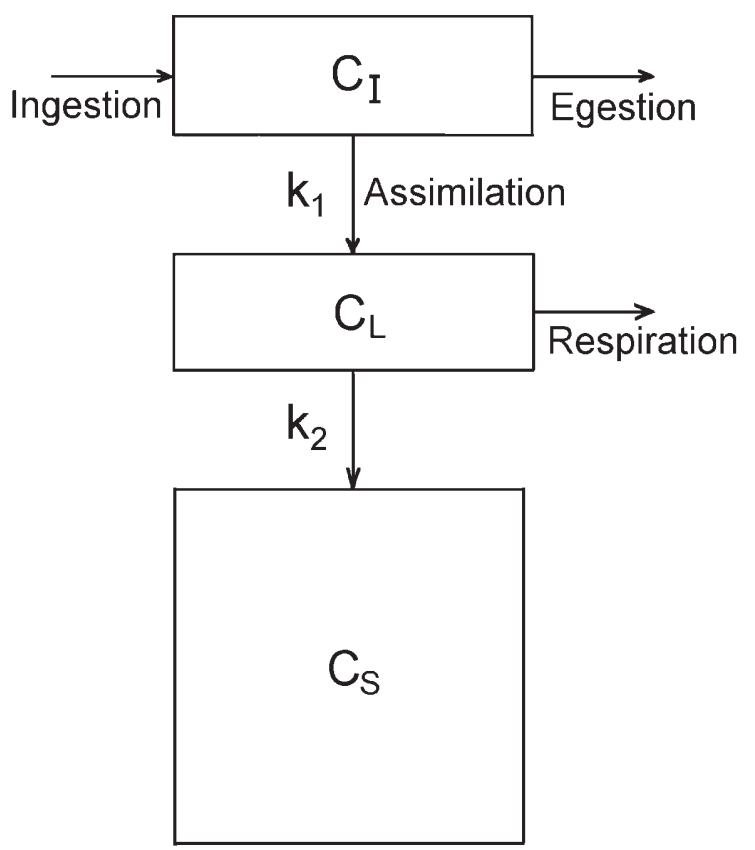

Figure 1. Diagram representation of the 3-compartment model for feeding and growth

The dynamics of individual mass compartments are defined as

$$
\begin{aligned}
& \Delta \mathrm{C}_{\mathrm{I}}=\text { Ingestion } \times \mathrm{AE}-\mathrm{k}_{1} \mathrm{C}_{\mathrm{I}} \\
& \Delta \mathrm{C}_{\mathrm{L}}=\mathrm{k}_{1} \mathrm{C}_{\mathrm{I}}-\text { Respiration }-\mathrm{k}_{2} \mathrm{C}_{\mathrm{L}} \\
& \Delta \mathrm{C}_{\mathrm{S}}=\mathrm{k}_{2} \mathrm{C}_{\mathrm{L}}
\end{aligned}
$$

\section{Methods}

\section{Production Model and its Extension}

The secondary production equations and parameter values presented by Lehman et al. (1997: Table 5) were adopted for this work, and they are reproduced in Table 1. The model requires specification of water temperature, neonate mass ( $\mu \mathrm{g} \mathrm{DW})$, and the mass ratio of fecund females at primaparity to neonates $\left(\mathrm{W}_{\mathrm{FINAL}} / \mathrm{W}_{0}\right)$. From these 3 specifications, model calculations produce rates of development, respiration, body mass versus time, and the rates of ingestion needed to sustain metabolism. In particular, total body carbon mass, $\mathrm{C}_{\mathrm{TOT}}$, and its variation with age is generated by the 1997 model from the input data. At each arbitrary time step, the increment in body mass $\Delta \mathrm{C}_{\mathrm{TOT}}$ can also be specified as

$$
\Delta \mathrm{C}_{\mathrm{TOT}}=(\text { Ingestion } \times \mathrm{AE}-\text { Respiration }) \Delta \mathrm{t}
$$


Table 1. Equations and parameter values for growth model of Bythotrephes (Lehman et al., 1997)

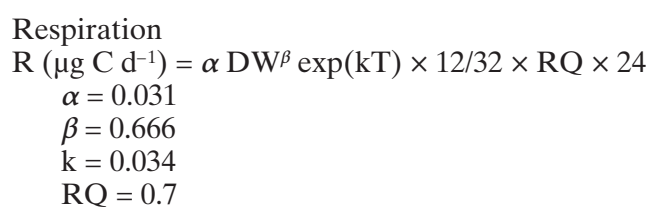

Development time of embryos from first appearance of eye pigment

$\mathrm{D}_{\mathrm{e}}$ (days) $=1 /[24 \exp (\mathrm{aT}+\mathrm{b})]$

$\mathrm{a}=0.101$

$\mathrm{b}=-5.547$

Development time from neonate to primaparous adult

$\Sigma \mathrm{D}$ (days) $=\Sigma \mathrm{F} \times \mathrm{D}_{\mathrm{e}}$ $\Sigma \mathrm{F}=6.705$

Dry Weight as function of relative age (relage), where relage ranges from 0 at birth to 1 at primaparity

$$
\begin{aligned}
& \mathrm{DW}(\mu \mathrm{g})=\mathrm{W}_{0} \times\left[\mathrm{W}_{\mathrm{FINAL}} / \mathrm{W}_{0}\right]^{\text {relage }} \\
& \mathrm{W}_{0}=\text { mass at birth } \\
& \mathrm{W}_{\text {FINAL }}=\text { mass of female at primaparity }
\end{aligned}
$$

Age

age $($ days $)=$ relage $\times \Sigma \mathrm{D}$

Carbon content

$\mathrm{C}(\mu \mathrm{g})=0.47 \times \mathrm{DW}$

Compartmental dynamics depend on establishing values for $\mathrm{k}_{1}, \mathrm{k}_{2}, \mathrm{C}_{\mathrm{I}}$, and $\mathrm{C}_{\mathrm{L}}$. $\mathrm{C}_{\mathrm{S}}$ can be calculated from $C_{\text {TOT }}-C_{I}-C_{L}$, and is not an independent variable. It is important to recognize, moreover, that the internal dynamics are constrained by ingestion, egestion and respiration. For example, if equation 4 is solved for a quasisteady state between ingestion and egestion (i.e., constant gut contents: $\Delta C_{I}=0$ ),

$$
\mathrm{k}_{1} \mathrm{C}_{\mathrm{I}}=\text { Ingestion } \times \mathrm{AE}=\Delta \mathrm{C}_{\mathrm{TOT}}+\text { Respiration }
$$

A similar constraint applies to the dynamics of pool $C_{L}$. At quasi steady state for pool $\mathrm{C}_{\mathrm{L}}$, equations 4 and 5 imply that

$$
\mathrm{k}_{2} \mathrm{C}_{\mathrm{L}}=[\text { Ingestion } \times \mathrm{AE}-\text { Respiration }]=\Delta \mathrm{C}_{\mathrm{TOT}}
$$

In the absence of empirical measurements for $\mathrm{k}_{1}, \mathrm{k}_{2}, \mathrm{C}_{\mathrm{I}}$, and $\mathrm{C}_{\mathrm{L}}$, but given the implicit constraints on their values set by mass balance considerations, the unknown compartment variables were estimated by inverse solution methods.

Growth of individual animals was simulated according to the equations in Table 1. Time steps were set equal to 0.01 of the temperature-dependent development time from neonate to primaparity (relative age $=0$ to 1 ), and integration was by finite difference. Calculations were performed for factorial combinations of temperature, neonate mass, and clutch size. A simulation model for the 3-compartment system was formulated as a spreadsheet in Excel $^{\circledR}$ version 9.0.2720. The Excel ${ }^{\circledR}$ 
"Solver" function for inverse solutions by iteration was used to solve for $\mathrm{k}_{1}$ and $\mathrm{k}_{2}$. Initial estimates for $\mathrm{C}_{\mathrm{I}}$ and $\mathrm{C}_{\mathrm{L}}$ at age $=0$ were set by the equations:

$$
\begin{aligned}
& \mathrm{C}_{\mathrm{I}}=\left(\Delta \mathrm{C}_{\mathrm{TOT}}+\text { Respiration }\right) / \mathrm{k}_{1} \\
& \mathrm{C}_{\mathrm{L}}=\Delta \mathrm{C}_{\mathrm{TOT}} / \mathrm{k}_{2}
\end{aligned}
$$

Values for $\Delta \mathrm{C}_{\mathrm{TOT}}$ and Respiration were obtained by calculation from the secondary production equations (Table 1). At each subsequent time step, incremental values of $C_{I}, C_{L}$, and $C_{S}$ were stipulated by equations 4 to 6 . The solution constraint was homeostasis of the ratio $\mathrm{C}_{\mathrm{L}} / \mathrm{C}_{\mathrm{S}}$ over the simulation period: neonate to primaparity. This constraint was selected by the rationale that labile metabolic compounds exist in a dynamic equilibrium with structural components. Specifically, the inverse model solutions were constrained to minimize the variance of $\mathrm{C}_{\mathrm{L}} / \mathrm{C}_{\mathrm{S}}$ over the 100 step simulation time period (i.e., relative age 0 to relative age 1 ). The resulting numerical solutions converged to reproducible values for $\mathrm{k}_{1}$ and $\mathrm{k}_{2}$ regardless of alternate initial value assumptions for $\mathrm{k}_{1}$ and $\mathrm{k}_{2}$ ranging from $5 \mathrm{~d}^{-1}$ to $25 \mathrm{~d}^{-1}$. Solutions reported here were generated with initial value assumptions for $\mathrm{k}_{1}$ and $\mathrm{k}_{2}$ equal to $10 \mathrm{~d}^{-1}$.

The simulation model was applied to factorial variations in 3 independent variables: temperature $(14,16,18,20$, and $22 \mathrm{C})$, clutch size $(3,6,9$, and 12$)$, and neonate mass $(40,80$, and $120 \mu \mathrm{g}$ DW). These variations encompass nearly the full empirical range of each variable observed in the North American Great Lakes (Sullivan and Lehman, 1998). Sullivan and Lehman (1998) demonstrated that the relative mass gain from neonate to primaparity is linearly related to clutch size at primaparity. Consequently, final mass at primaparity $\left(\mathrm{W}_{\text {FINAL }}\right)$ was calculated from neonate mass $\left(\mathrm{W}_{0}\right)$ according to

$$
\mathrm{W}_{\text {FINAL }}=(1.16 \text { Clutch }+2.06) \mathrm{W}_{0}
$$

\section{Experimental Measurement of Prey Digestion Rates}

Bythotrephes cederstroemi collected from offshore Lake Michigan were isolated in 5 -ml tissue culture wells filled with filtered ( $\mathrm{GF} / \mathrm{C})$ lake water and starved for at least 24-h at 16 C. Prey were alternatively Artemia salina nauplii, hatched from resting eggs in $10 \%$ o $\mathrm{NaCl}$, then rinsed copiously in lake water immediately before feeding, or Daphnia pulex from a clonal culture established from a female collected at Whitmore Lake, Washtenaw County, Michigan. Daphnia were offered by hand with watchmaker forceps applied to their tail spines and consumption was observed microscopically. Time marking for Daphnia prey began when the predator completed feeding and discarded exoskeletal remains from its clutches. Time marking for Artemia began immediately because the nauplii were ingested with discard of relatively little debris. At prescribed time intervals, predators were frozen on Teflon disks over Dry Ice, and were held at $-80^{\circ} \mathrm{C}$ until analysis.

In Trial 1, Bythotrephes were fed single Daphnia and 24 replicate predators were held at $16 \mathrm{C}$ for $0,0.5,1,2$, or $3 \mathrm{~h}$. In Trial 2, Bythotrephes were fed a single Artemia nauplius and 12 replicate predators were held at $16 \mathrm{C}$ for $0 \mathrm{~h}$ or $0.5 \mathrm{~h}$. In Trial 3, 
Bythotrephes fed ad libitum on Artemia. After 10 h, 12 Bythotrephes with visibly filled guts were collected $(0 \mathrm{~h})$, and another 12 predators with initially full guts were isolated in filtered lake water for $2 \mathrm{~h}$.

Electrophoresis and staining procedures followed Hebert and Beaton (1989) with the following modifications. Gels were run for $25 \mathrm{~min}$ at $200 \mathrm{~V}$ and $22 \mathrm{C}$ in TrisGlycine buffer at $\mathrm{pH}$ 8.5. Stains were concentrated to intensify detection limits by reducing oxidative intermediates and diluting agents. Gels were scored manually and migration distances were measured to $0.025 \mathrm{~mm}(0.001 \mathrm{inch})$ using a dial caliper. Migration distances were measured from the origin of application to the middle of the stained band. Of the ten lanes used on each gel, 2 were used for starved predators, and 2 were for the standard prey. Prey bands were denoted with " $Y$ " and were numbered sequentially from slow to fast mobility. For instance, the Ao loci for Daphnia in Trial 1 exhibited two bands: Y1 and Y2. Predator bands were labeled " $\mathrm{R}$ " and were numbered sequentially according to increasing mobilities.

\section{Results}

\section{Model Results}

Inverse model solutions for $\mathrm{k}_{1}$ (net rate of digestion) and $\mathrm{k}_{2}$ (net rate of tissue accumulation) are shown in Figure 2 for the simulated ranges of temperature, clutch size, and neonate mass. The rate constants $\mathrm{k}_{1}$ and $\mathrm{k}_{2}$ are highly correlated $(\mathrm{R}=0.99)$, a consequence of assumed homeostatic growth. Ranges of model solutions for
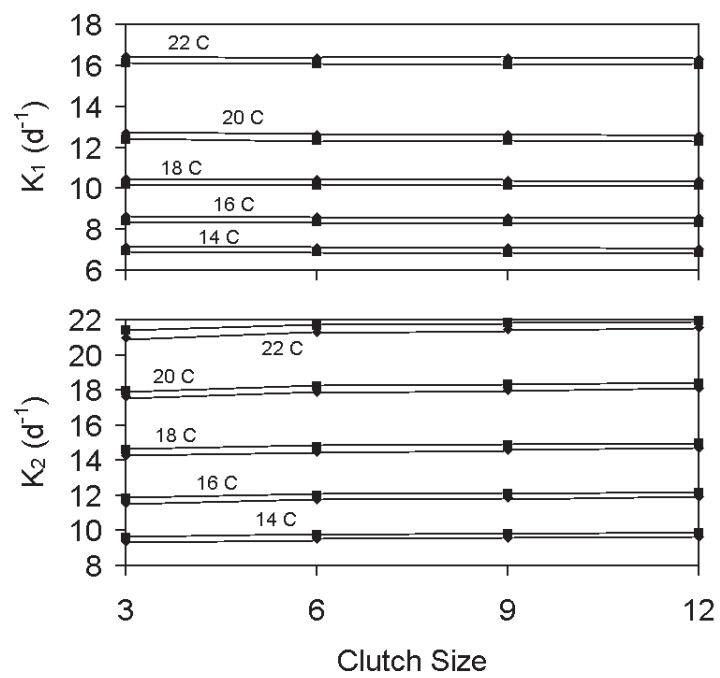

Figure 2. Inverse model solutions for $\mathrm{k}_{1}$ (rate constant of digestion, $\mathrm{d}^{-1}$ ) and $\mathrm{k}_{2}$ (rate constant of tissue accumulation, $\mathrm{d}^{-1}$ ) for the simulated ranges of temperature, clutch size, and neonate mass. Temperature-related results are for $22,18,16$, and $14 \mathrm{C}$ from top to bottom respectively in each panel. Results by neonate mass are shown for 40 (triangles) and 120 (squares) $\mu \mathrm{g} \mathrm{DW}$ 
Table 2. Ranges of model solutions for $\mathrm{C}_{\mathrm{I}} / \mathrm{C}_{\mathrm{TOT}}$ (gut contents as proportion of total carbon mass) and $\mathrm{C}_{\mathrm{L}} / \mathrm{C}_{\mathrm{TOT}}$ (labile pool fraction of total carbon mass) obtained in simulations involving factorial combinations of the specified variables

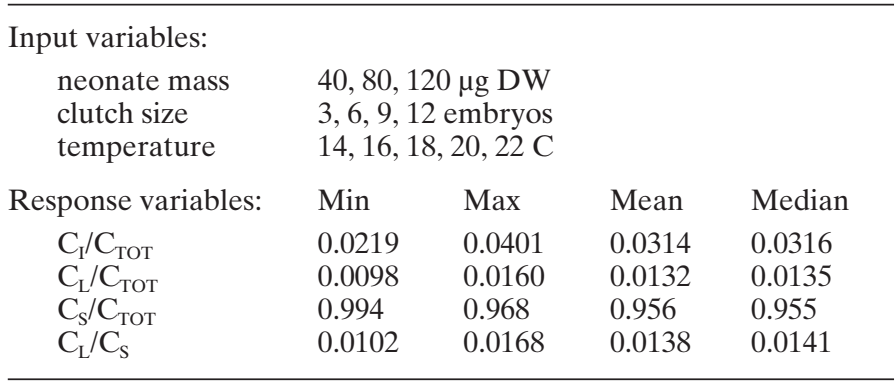

$\mathrm{C}_{\mathrm{I}} / \mathrm{C}_{\text {Тот }}$ (gut content fraction) and $\mathrm{C}_{\mathrm{L}} / \mathrm{C}_{\mathrm{TOт}}$ (labile metabolic pool fraction) are reported in Table 2 . The results imply that $\mathrm{C}_{\mathrm{I}}$ represents about 3 percent and $\mathrm{C}_{\mathrm{L}}$ represents about 1 percent of the total mass of the predator, and so structural tissue is about 96 percent of the total body mass.

A time scale for digestion of gut contents permitting comparison with independent empirical data can be defined as the half-time for the digestion process. If $Y_{0}$ represents the carbon mass of an ingested prey item, the residual undigested mass over time is defined as

$$
\mathrm{Y}(\mathrm{t})=\mathrm{Y}_{0} \exp \left(-\mathrm{k}_{1} \mathrm{t} / 24\right)
$$

where $t$ is measured in hours. The half-time $\left(t_{1 / 2}\right)$ is

$$
\mathrm{t}_{1 / 2}=0.693 \times 24 / \mathrm{k}_{1}
$$

Both $\mathrm{k}_{1}$ and $\mathrm{k}_{2}$ are correlated mainly with temperature $\left(\mathrm{r}^{2}>0.96\right)$, and the nearlinear relationships are

$$
\begin{aligned}
& \mathrm{k}_{1}=1.122(\mathrm{SE}=0.029) \text { Temp }-9.31(\mathrm{SE}=0.53) \\
& \mathrm{k}_{2}=1.497(\mathrm{SE}=0.020) \text { Temp }-11.77(\mathrm{SE}=0.36)
\end{aligned}
$$

Using the equation for $\mathrm{k}_{1}$ as a predictor, half-times for prey digestion range from $2.6 \mathrm{~h}$ at $14 \mathrm{C}$ to $1.1 \mathrm{~h}$ at $22 \mathrm{C}$.

\section{Turnover of Structural Tissue}

Inverse model solutions also permit estimation of the turnover rate for structural tissue. These rates are analogous to rates of tissue labeling for a consumer fed with radiotracer labeled prey (e.g., Dagg, 1974; Lampert and Gabriel, 1984; Lehman and Naumoski, 1985; Branstrator and Lehman, 1989; Branstrator, 1994). Because $C_{S}$ 
(structural tissue) is the dominant biomass pool, the main dynamic is set by the rate of accumulation of $\mathrm{C}_{\mathrm{S}}$ :

$$
\mathrm{dC}_{\mathrm{S}} / \mathrm{dt}=\mathrm{k}_{2} \mathrm{C}_{\mathrm{L}}
$$

Across the full ranges of simulated conditions, the mean ratio of $\mathrm{C}_{\mathrm{L}}$ to $\mathrm{C}_{\mathrm{S}}$ was 0.0138 $(\mathrm{CV}=0.0067, \mathrm{n}=60)$. Hence, the turnover of structural biomass pool $\mathrm{C}_{\mathrm{S}}$ closely approximates a first-order process with

$$
\mathrm{dC}_{\mathrm{S}} / \mathrm{C}_{\mathrm{S}} \mathrm{dt}=0.0138 \mathrm{k}_{2}
$$

This suggests that the apparent rate constant for turnover of structural tissue in Bythotrephes ranges from about $0.127 \mathrm{~d}^{-1}$ at $14 \mathrm{C}$ to $0.292 \mathrm{~d}^{-1}$ at $22 \mathrm{C}$, corresponding with apparent half-times of 5.47 to 2.37 days, respectively.

\section{Experimental Detection Times for Prey Enzymes}

Table 3 reports mobilities for prey and predator enzyme loci. Daphnia allozymes are undetectable after $1 \mathrm{~h}$ digestion by Bythotrephes (Fig. 3). Artemia allozymes degrade rapidly, as well. Single nauplii cannot be detected $30 \mathrm{~min}$ after ingestion, and even when the predators have guts filled with prey, no Artemia allozymes are detectable after $2 \mathrm{~h}$ digestion (Fig. 4). The empirical time scales of prey enzyme digestion by Bythotrephes thus conform relatively well with model-inferred halftimes of digestion (i.e., less than 2 hours for both at temperatures around $16 \mathrm{C}$ ).

Table 3. Mean allozyme mobilities and coefficients of variation (SD/mean) for each locus in the three experimental trials reported in the text. Prey bands are denoted "Y" and predator bands are denoted "R". Numbers are in order of increasing mobility

\begin{tabular}{llllrl}
\hline Trial & Locus & Band & Mean Mobility $(\mathrm{cm})$ & $\mathrm{n}$ & $\mathrm{CV}(\%)$ \\
\hline 1 & Pgi & Y1 & 3.12 & 91 & 1.82 \\
& & R1 & 3.41 & 128 & 2.02 \\
& Ao & Y1 & 4.43 & 91 & 3.12 \\
& & Y2 & 4.58 & 91 & 3.11 \\
2 & R1 & 3.93 & 128 & 3.15 \\
& & Y1 & 0.16 & 20 & 6.72 \\
& Pgi & Y2 & 0.33 & 20 & 3.42 \\
& & Y3 & 0.57 & 20 & 1.85 \\
& & R1 & 3.45 & 32 & 0.78 \\
& & Y1 & 2.70 & 20 & 1.81 \\
3 & Ldh & R1 & 2.34 & 32 & 2.65 \\
& & Y1 & 0.16 & 14 & 4.87 \\
& & Y2 & 0.33 & 17 & 2.93 \\
& & Y3 & 0.58 & 17 & 1.74 \\
& & R1 & 3.45 & 32 & 0.33 \\
& & Y1 & 2.74 & 17 & 0.44 \\
& & R1 & 2.36 & 32 & 0.59 \\
\hline
\end{tabular}


Trial 1: Daphnia

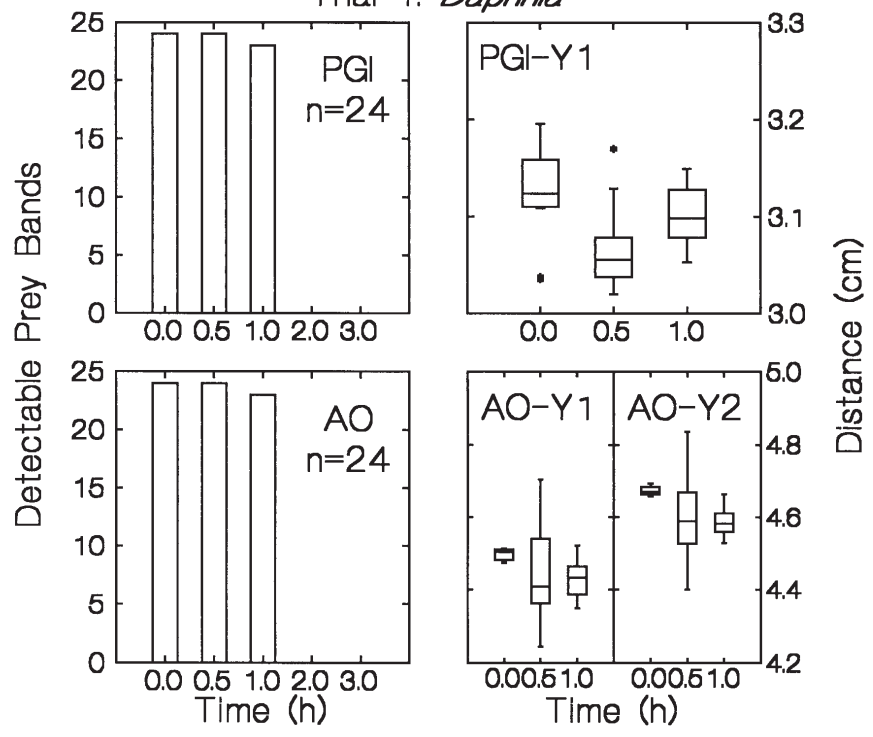

Figure 3. Results for feeding Trial 1, where predator is Bythotrephes and prey is Daphnia pulex. Left: number of prey detectable, out of 24 possible, after indicated digestion times. Right: mobilities of detectable Daphnia bands at each locus at indicated digestion times. No prey was detectable at 2 or $3 \mathrm{~h}$

Trial 2 Artemia Trial 3

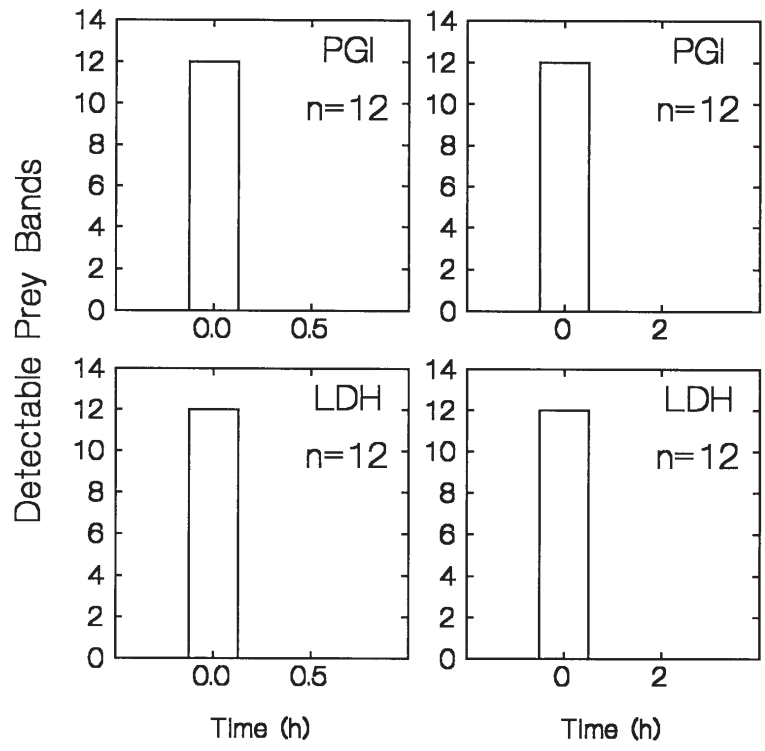

Figure 4. Results for feeding Trials 2 and 3, where predator is Bythotrephes and prey is Artemia salina. Number of prey detectable, out of 12 possible, after indicated digestion times 


\section{Discussion}

The inverse model approach described in this paper permits estimation of rate constants for comparison with empirical data. The values for $\mathrm{k}_{1}$ estimated here can be compared with the rate constant for assimilation by Bythotrephes that was measured by Lehman (1993) and Lehman and Branstrator (1996) by a dual-isotope technique. The turnover time of $1.42(\mathrm{SE}=0.65) \mathrm{h}$ reported by Lehman and Branstrator (1996) encompasses a range of rate constants that are statistically indistinguishable from our model-estimated $\mathrm{k}_{1}$ in this report.

Validity of the inverse model rate constant $\mathrm{k}_{2}$ is difficult to test at present. Time courses of radiolabeling have been reported by Lampert and Gabriel (1984), Lehman and Naumoski (1985), and Branstrator (1994) for herbivorous Cladocera feeding on radiolabeled algae, but no similar time course data are available for Bythotrephes feeding on animal prey. By analogy with the phylogenetically related taxa, half-times of 2 to 3 days for isotope equilibrium at ca. $20 \mathrm{C}$ seem too long by perhaps a factor of 2 or 3 . The reason for the long model-predicted times is our formulation of $\mathrm{k}_{2}$ as a net rate constant, rather than as a net sum of two opposing fluxes. There is no point in introducing an additional variable in the present model; it is true that by doing so the predicted turnover rate could be reduced at will, but there are no empirical data suitable for calibration.

Our direct test for the digestion rate constant $\mathrm{k}_{1}$ was based on the time-course of detection of prey allozymes. The rationale for this approach is based on the logic that assay conditions dictate a detection threshold for each allozyme detection system, and that the initial amount of allozyme present in a prey item $\left(\mathrm{A}_{0}\right)$ degrades according to the digestion rate constant:

$$
\mathrm{A}(\mathrm{t})=\mathrm{A}_{0} \exp \left(\mathrm{k}_{1} \mathrm{t}\right)
$$

Thus, detection time is linearly proportional to digestion half-time. In practice, the two times may be almost the same because as an enzyme becomes half-digested, it is unlikely to retain much of its catalytic function. Hartman and Garton (1992) found that prey enzymes could be detected in the stomachs of walleye (Stizostedion vitreum) by starch gel electrophoresis until the prey had been digested $40 \%$ by weight.

Digestion of ingested prey protein is obviously not immediate, or the allozymes would immediately become nonfunctioning and undetectable. This digestion time period imposes a minimum constraint for gut passage time and sets an upper limit on prey consumption rates (Lehman, 1976) for predators of this type. The preoral manipulations and discard of exoskeleton practiced by Bythotrephes may be costeffective ways, in terms of the time budget, to ensure rapid action by proteases and maximal effective use of gut volume. Otherwise, gut retention would have to be longer and fewer prey items could occupy the gut at one time.

Turnover time of 1 to $2 \mathrm{~h}$ for gut contents is an important consideration in the foraging time budget of the predator. Burkhardt and Lehman (1994, Table 3) demonstrated that handling times range from about 6 to $30 \mathrm{~min}$ with Daphnia prey of different sizes by the various instar stages of Bythotrephes. These times represent preoral manipulations, shredding, and ingestion until discard of non- 
ingested debris. The predator cannot search for or capture additional prey while it is thus occupied with a meal. Only about $58 \%$ of the total prey contents of $\mathrm{P}$ and C are ingested (Burkhardt, 1991; Burkhardt and Lehman, 1994; Lehman, 1993), but of those, about $85 \%$ are assimilated. RQ and changes in tissue stoichiometries indicate that the animals subsist on a relatively equal mixture of lipids and proteins (Lehman et al., 1997). Thus the prey allozymes are likely tracers for the digestion time and gut turnover of a major nutritional component, prey protein.

Bythotrephes exhibits trophic transfer efficiencies of $25 \%$ or more (Lehman and Branstrator 1995), and is capable of rapid parthenogenic population growth, making it a potent but opportunistic agent of predation. Its life history traits are part of a suite of characters that includes preoral prey manipulations, rapid gut turnover, and high assimilation efficiency.

\section{Summary and Conclusion}

Several independent lines of evidence support the conclusion that assimilation of ingested prey material is extremely rapid for aquatic invertebrate predators like Bythotrephes that shred their prey before ingesting it. At environmental temperatures typically experienced by populations in nature, gut contents provide a reliable window into little more than the previous one hour of feeding activity, and even that can be compromised by collection conditions. This temporal bias has long been known for other invertebrate predators, and the broad caveats applied to those other predators apply to predatory Cladocera, as well. For this reason, we developed a stoichiometry-based mass balance approach for estimating prey identity and quantity (Lehman and Branstrator, 1995; Lehman et al., 1997).

It is feasible to adapt the inverse modeling approach described here to alternative formulations of the growth rate function, such as might occur during episodic bouts of starvation. While possible, that application and others like it would be speculative at this time in the absence of a coherent data set for validation. Despite limitations of current data, inverse solution methods provide a convenient way to tease useful kinetic information from complicated process models, and they can be adopted as part of integrated experimental and analytical studies.

By inverse model methods we were able to estimate rate constants and halftimes for prey digestion, as well as relative pool sizes of structural, metabolic, and gut content material. We were able to model differences in rates and pool sizes as functions of temperature, clutch sizes, and neonate mass. Model results agree with independent empirical measurement of prey digestion rates, they confirm that the true rates are two hours or less, and they provide additional quantitative predictions that can serve as a stimulus for future experimentation.

\section{ACKNOWLEDGEMENTS}

This work was supported in part by grants from the U.S. National Science Foundation program in Biological Oceanography. 


\section{REFERENCES}

Branstrator, D.K., 1994. Profitability of cladoceran prey for Leptodora kindtii. Verh. Internat. Verein. Limnol. 25: 2413-2417.

Branstrator, D.K. and J.T. Lehman, 1989. Measuring ingestion and assimilation efficiencies of aquatic invertebrate predators. H. R. Rackham Research Partnership Program, Copyrighted Research Plan, U. S. Library of Congress

Burkhardt, S., 1991. Phosphorus turnover, prey consumption, and size variation of the predatory cladoceran Bythotrephes cederstroemi. M.S. Thesis, Univ. of Michigan, Ann Arbor.

Burkhardt, S. and J.T. Lehman, 1994. Prey consumption and predatory effects of an invertebrate predator (Bythotrephes: Cladocera, Cercopagidae) based on phosphorus budgets. Limnol. Oceanogr. 39: 1007-1019.

Conover, R.J. and V. Francis, 1973. The use of radioactive isotopes to measure the transfer of materials in aquatic food chains. Mar. Biol. 18: 272-283.

Dagg, M.J., 1974. Loss of prey body contents during feeding by an aquatic predator. Ecology 55: 903-906.

Edmondson, W.T., 1960. Reproductive rates of rotifers in natural populations. Mem. Ist. Ital. Idrobiol. 12: 21-77.

Edmondson, W.T., 1965. Reproductive rate of planktonic rotifers as related to food and temperature in nature. Ecol. Monogr. 35: 61-111.

Giller, P.S., 1982. The natural diets of waterbugs (Hemiptera-Heteroptera): electrophoresis as a potential method of analysis. Ecol. Entomol. 7: 233-237.

Giller, P.S., 1984. Predator gut state and prey detectability using electrophoretic analysis of gut contents. Ecol. Entomol. 9: 157-162.

Giller, P.S., 1986. The natural diet of the Notonectidae: field trials using electrophoresis. Ecol. Entomol. 11: 163-172.

Hagler, J.R. and S.E. Naranjo, 1994. Qualitative survey of two Coleopteran predators of Bemisia tabaci (Homoptera: Aleyrodidae) and Pectinophora gossypiella (Lepidoptera: Gelechiidae) using a multiple prey gut content ELISA. Environ. Entomol. 23: 193-197.

Hall, D.J., 1964. An experimental approach to the dynamics of a natural population of Daphnia galeata mendotae. Ecology 45: 94-112.

Hartman, K.J. and D.W. Garton, 1992. Electrophoretic identification of partially digested prey of piscivorous fish. North Amer. J. Fish. Management 12: 260-263.

Hebert, P.D.N. and M. J. Beaton, 1989. Methodologies for allozyme analysis using cellulose acetate electrophoresis. Helena Technical Laboratories, 30 p.

Lampert, W. and W. Gabriel, 1984. Tracer kinetics in Daphnia: an improved two-compartment model and experimental test. Arch. Hydrobiol. 100: 1-20.

Lehman, J.T., 1976. The filter feeder as an optimal forager, and the predicted shape of feeding curves. Limnol. Oceanogr. 21: 501-516.

Lehman, J.T., 1993. Efficiencies of ingestion and assimilation by an invertebrate predator using C and P dual isotope labeling. Limnol. Oceanogr. 38: 1550-1554.

Lehman, J.T. and T. Naumoski, 1985. Content and turnover rates of phosphorus in Daphnia pulex: Effect of food quality. Hydrobiologia 128: 119-125.

Lehman, J.T. and D.K. Branstrator, 1995. A model for growth, development, and diet selection by the invertebrate predator Bythotrephes cederstroemi. Journal of Great Lakes Res. 21: 610-619.

Lehman, J.T. and D.K. Branstrator, 1996. Predicting assimilation and development rates of invertebrate predators. J. Great Lakes Res. 22: 930-934.

Lehman, J. T., D. M. Bilkovic and C. Sullivan, 1997. Predicting development, metabolism and secondary production for the invertebrate predator Bythotrephes. Freshwater Biol. 38: 343-352.

Lister, A., M.B. Usher and W. Block, 1987. Description and quantification of field attack rates by predatory mites: an example using an electrophoresis method with a species of Antarctic mite. Oecologia 72: 185-191.

Murray, R.A. and M.G. Solomon, 1978. A rapid technique for analysing diets of invertebrate predators by electrophoresis. Ann. Appl. Biol. 90: 7-10.

Parsons, T.R., M. Takahashi and B. Hargrave, 1984. Biological Oceanographic Processes. $3^{\text {rd }}$ edition. Pergamon. 
Schulz, K.L. and P.M. Yurista, 1995. Diet composition from allozyme analysis in the predatory cladoceran Bythotrephes cederstroemi. Limnol. Oceanogr. 40: 821-826.

Sopp, P.I., K.D. Sunderland, J.S. Fenlon and S.D. Wratten, 1992. An improved quantitative method for estimating invertebrate predation in the field using an enzyme-linked immunosorbent assay (ELISA). J. Appl. Ecol. 29: 295-302.

Sullivan, C.W. and J.T. Lehman, 1998. Character variation and evidence for spine length selection in the invertebrate predator Bythotrephes (Crustacea: Cladocera) from Lakes Michigan, Huron, and Erie. Archiv Hydrobiol. (in press).

Sunderland, K.D., 1988. Quantitative methods for detecting invertebrate predation occurring in the field. Ann. Appl. Biol. 112: 201-224.

Wright, D.J., 1965. The population dynamics and production of Daphnia in Canyon Ferry Reservoir, Montana. Limnol. Oceanogr. 10: 583-590.

Received 25 May 1999;

revised manuscript accepted 11 October 2000.

To access this journal online:
http://www.birkhauser.ch 